\title{
The Impact of Financialization on Profitability of Real Estate Enterprises
}

\author{
Shu $\mathrm{Wu}^{*}$ \\ School of Economics and Management \\ Jiangxi University of Science and Technology \\ Ganzhou, 341000, China \\ 1689935622@qq.com
}

\author{
Yiding $\mathrm{Wu}$ \\ School of Economics and Management \\ Jiangxi University of Science and Technology \\ Ganzhou, 341000, China \\ wid0410@163.com
}

\begin{abstract}
In recent years, the trend of financial and financial development in China has been increasing. The real estate industry, as an important industry of national economy, its financialization is becoming more and more obvious. In this paper, financial data of $\mathrm{A}$-share real estate listed companies in Shanghai and Shenzhen from 2008 to 2017 were selected as samples, it aims to test the relationship between financialization of real estate enterprises and corporate profitability by using Bidirectional fixed effect model. The empirical results show that there is a significant negative correlation between the financialization of real estate enterprises and their profitability, that is, the financialization of real estate enterprises will inhibit their profitability. The research in this paper is not only beneficial to supplement and improve the micro-economic effect of the financialization of real estate enterprises, but also has a strong reference significance for the actual operation of real estate enterprises and government financial supervision.
\end{abstract}

Keywords-Real estate enterprise; Financialization; Profitability; Bidirectional fixed effect model

\section{INTRODUCTION}

Since entering the 21st century, China's economic financialization degree is increasing. Financialization means that the profits of economic activities are mainly obtained through financial activities rather than the production and trade of commodities [1], the financialization of enterprises is a reflection of economic financialization in micro level. Some research defined the increasing proportion of profits obtained from financial speculation and investment activities in GDP as financialization [2]

As China's economy enters the new normal, as an important industry of China's national economy, the real estate industry is becoming increasingly financialized. Real estate enterprises have capital-intensive, fixed and cyclical characteristics, coupled with the fierce market competition environment and the restrictions of national credit policies, making it difficult for them to successfully raise and adjust funds through the market mechanism. In this context, real estate enterprises strengthen cooperation with financial institutions, which is conducive to increasing the sources of funds, diversifying risks, improving product quality and so on. However, excessive financialization of real estate enterprises will aggravate the financial risks faced by enterprises, damage the stable development of real estate enterprises, and may also affect the effect of China's real estate regulatory policies [3].

As a for-profit organization, the essence of its economic behavior is to pursue and create profits. So in the current context, how is the financial status of the real estate industry? Does its financialization improve or reduce the profitability of enterprises? The answers to these questions are not only conducive to deepening the micro-economic consequences of the financialization of the real estate industry, but also of great reference significance for the government to formulate and implement financial policies under the new normal of the economy. Therefore, this is an important and realistic problem to be solved.

In summary, this paper based on the above problems, takes the hot issue of real estate financialization as the starting point, selects real estate listed companies in Shanghai and Shenzhen A-shares from 2008 to 2017 as research samples, constructs a Bidirectional fixed effect model, and empirically tests the impact of real estate financialization on corporate profitability.

The structure of this study is organized as follows: in the next section, literature review on the connotation and motivation of financialization of entity enterprises and its influence on enterprises are discussed. Section 3 explains the source of data, defines relevant variables, constructs an analysis model and makes empirical analysis. The next section shows the results obtained. Then constructs the discussions about why we come out these results. The last section summarizes the full paper, draws the main conclusion.

\section{LITERATURE REVIEW}

\section{A. The connotation and motivation of financialization of entity enterprises}

Since the 1980s, the increasing trend of financialization in international economy has triggered the research on financialization by scholars. On the connotation of financialization, some hold that financialization of nonfinancial enterprises is the investment and financing demand of enterprises, and enterprises are more inclined to financial investment [4]. Other research mainly defines financialization from two perspectives: from the perspective of behavior, financialization reflects that enterprises invest more in capital 
market and neglect or even abandon productive investment; As a result, more profits of enterprises come from financial channels [5].

There are three main theories about the motivation of enterprises to hold a large number of financial assets or even enter the financial industry in existing researches: precautionary saving theory, also known as "reservoir" theory [6][7], which is similar to the precautionary incentive to hold cash. The next theory is investment substitution theory: in order to maximize profits, enterprises replace real economy investment with financial asset investment [8]. The third explanation is the theory of "entity intermediation" proposed for the phenomenon of enterprise financialization in emerging market countries.

It can be seen from existing studies that the motivation of financialization of enterprises is different: some found that the reason for financialization of enterprises in developed countries is to prevent the risk of capital shortage, with precautionary savings as the main motivation [9], and some found that the motivation of financialization of Chinese enterprises is to pursue profits, not precautionary savings [10].

\section{B. The influence of financialization of entity enterprises}

From the existing literature, scholars mainly study the influencing factors and economic effects of financialization from the macro and micro levels. From the point of the research of macro level: financialization prompted companies put excessive economic resources into financial markets, easy to cause industrial hollowing out[11], had a similar conclusion, they think enterprise financialization has an obvious inhibiting effect on the real interest rates [12].

At the macro level, most people hold a negative attitude towards the influence of financialization, believing that financialization will inhibit the healthy development of economy. The conclusions about the influence of financialization on economy at micro level are not consistent. Some scholars believe that financialization of enterprises is conducive to optimizing capital allocation and helping enterprises to diversify their operations so as to diversify their business risks [13]. However, most studies believe that financialization has a greater negative impact on the economy. For example, financialization will inhibit the production efficiency of operational businesses and hinder the competitiveness of enterprises in operating core businesses [14]. Some scholars studied the listed manufacturing companies in China, and the results showed that there was a significant negative correlation between financialization of entity enterprises and enterprise innovation [15].

According to the existing studies, the study of the impact between economic behavior and financialization can be divided into two aspects: the macrocosm and microcosm. At the macro level, excessive financialization will occupy the enterprise internal resources, limiting development of other departments, making the development of the real economy resources too much idle and bring industrial hollowing out , and even cause the problem of unemployment, obstacles to the real economy stable and healthy development. Studies at the micro level mainly focus on the whole market or only on the manufacturing industry, believing that the financial behavior of enterprises internally pushes up the leverage ratio of enterprises, thus affecting the business performance and technological innovation of enterprises, and inhibiting the production efficiency of business operations.

In China, with the development of urbanization, the real estate industry has become one of the important pillar industries of the national economy. However, at present, researches on the financialization of real estate enterprises mainly focus on the macro level. Although they can grasp the general trend on the whole, they are still lacking in operability and pertinence. So, this paper starting from the micro level, focuses on the impact of financialization on the profitability of real estate enterprises, which has strong practical significance.

\section{DATA AND METHODOLOGY}

\section{A. Data}

We investigate the impact of financialization on corporate profitability of the real estate enterprises. For this purpose, the equation is estimated with the Bidirectional fixed effect model.

$$
\begin{aligned}
& \text { ROE }=\alpha+\beta_{1} \text { FINi, } t+\beta_{2} \text { LEV }_{i, t}+\beta_{3} \text { GROWTH }_{i, t}+\beta_{4} \text { TAT }_{i, t}+\mu_{i}+\lambda_{t} \\
& +\mathrm{e}_{\mathrm{i}, \mathrm{t}}
\end{aligned}
$$

We used the proportion of financial assets to total assets (FIN), the asset-liability ratio (LEV), the growth rate of main business income (GROWTH), asset turnover ratio (TAT), and return on equity (ROE) as data in this study. Existing theories and empirical studies show that corporate profitability is also affected by financial leverage, enterprise growth, total asset turnover and other factors. Therefore, in order to optimize the research effect, this paper select LEV, GROWTH and TAT as control variables.

Data were gathered on yearly basis from 2008 to2017, and sample companies selected according to the following principles :(1) excluding all listed companies with ST, ST* and B-shares; (2) eliminate companies with incomplete data; (3) in order to reduce the influence of outliers, this paper conducts Winsorize tail reduction for all data with continuous variables between $0 \sim 1 \%$ and $99 \% \sim 100 \%$. Finally, 80 listed companies in the real estate industry were selected as research objects. All the original data in this paper were taken from the Oriental wealth choice financial database, and STATA 11.0 is used in order to carry out in this study.

The financial assets of the real estate enterprises, this paper refers to a previous literature, use the summary of monetary funds, financial derivatives, short-term investments, transactional financial assets, interest receivable, buy-and-sell financial assets, available-for-sale financial assets, hold-tomaturity investments, and long-term receivables as the financial assets [7]

\section{B. Empirical Analysis}

\section{1) Descriptive statistics}

The descriptive statistics of the variables used in the regression analysis are presented in TABLE I. As can be seen from TABLE I, the average return on equity of the real estate industry is $9.73 \%$, but there is a big gap between the minimum 
value of $-37.69 \%$ and the maximum value of $41.79 \%$, and its range is $79.48 \%$. This data indicates that there is a significant "wealth gap" between the industries, and also reflects the high risk of the real estate industry from the side. The external economic environment may have changed significantly during the decade from 2008 to 2017 , that leading to significant changes in ROE.

TABLE I. DESCRIPTIVE STATISTICS OF SELECTED VARIABLES

\begin{tabular}{|l|c|c|c|c|c|}
\hline & Mean & $\mathbf{p 5 0}$ & Sd & Min & Max \\
\hline ROE & 0.0973 & 0.0942 & 0.1061 & -0.3769 & 0.4179 \\
\hline FIN & 0.0648 & 0.033 & 0.0835 & 0.0001 & 0.4308 \\
\hline LEV & 0.6397 & 0.6602 & 0.1577 & 0.1584 & 0.9197 \\
\hline GROWTH & 0.2468 & 0.1163 & 0.7478 & -0.8435 & 4.5932 \\
\hline TAT & 0.2783 & 0.2471 & 0.1617 & 0.0098 & 0.8857 \\
\hline
\end{tabular}

The mean value of independent variable FIN is 6\%, it means that the average financialization degree of the industry is not high, but the maximum value reaches $43 \%$, that is, the proportion of financial assets held by enterprises in the total assets is as high as $43 \%$, indicating that there are enterprises with high financialization degree in the real estate industry, and the trend of financialization is obvious. The financial asset holdings of the industry are on the rise, and the degree of financialization of China's real estate enterprises is gradually deepening

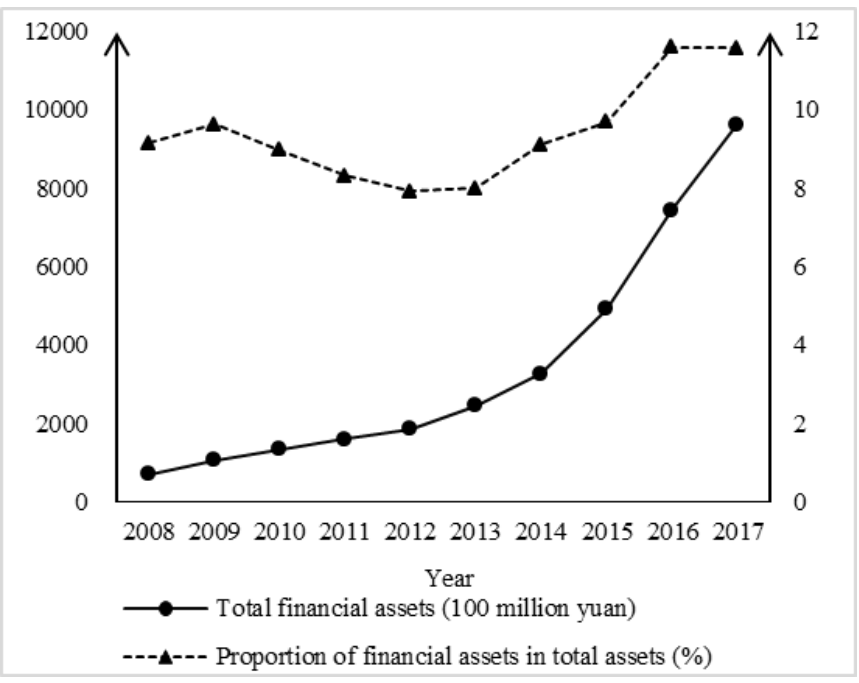

Fig. 1. The trend chart of the financial assets holding and financialization

Fig.1 shows the same result, the financial assets allocated by China's listed real estate companies increased from 70.37 billion Yuan in 2008 to 963.944 billion Yuan in 2017, an increase of 12.7 times in just 10 years. From the perspective of the proportion of financial assets in the total assets, although there is a slight increase or decrease, the overall trend is still on the rise, from $9.15 \%$ in 2008 to $11.59 \%$ in 2017 , with an increase of $26.57 \%$

\section{2) Multicollinearity test}

In order to avoid the multicollinearity problem in the regression model, Pearson test was carried out among the continuous variables in the model.

TABLE II. CORRELATION COEFFICIENTS OF THE SELECTED VARIABLES

\begin{tabular}{|c|c|c|c|c|c|}
\hline Variables & ROE & FIN & LEV & GROWTH & TAT \\
\hline ROE & 1.000 & & & & \\
\hline FIN & $-0.079 * *$ & 1.000 & & & \\
\hline LEV & $0.101 * * *$ & $-0.274 * *$ & 1.000 & & \\
\hline GROWTH & $0.199 * * *$ & $-0.065^{*}$ & 0.039 & 1.000 & \\
\hline TAT & $0.226 * * *$ & $-0.189^{* * *}$ & $0.122 * * *$ & $0.166 * * *$ & 1.000 \\
\hline
\end{tabular}

As can be seen from TABLE II, although all variables show certain correlation, the maximum correlation coefficient is no higher than 0.25 . It is generally believed that when the Pearson correlation coefficient of all variables is lower than the threshold value of collinearity, 0.7 , no serious multicollinearity problem will occur in the empirical analysis, so the research conclusion of this paper will not be affected by multicollinearity problem.

In addition, according to Pearson among variables, the degree of financialization of real estate enterprises has a negative impact on corporate profitability, and financial leverage, enterprise growth and total asset turnover are all positively correlated with corporate profitability. However, the correlation only considers the correlation between two variables and ignores the influence of other factors, which needs to be further tested.

\section{EMPIRICAL RESULTS}

1. The test results show that the coefficient of FIN is 0.186 , which is significant at the level of $10 \%$, indicating that there is a significant negative correlation between the level of financialization of real estate enterprises and corporate profits, that is, the higher the degree of financialization of enterprises, the stronger the inhibition on the profitability of real estate enterprises.

2. As can be seen from TABLE I and Fig.1, the degree of financialization of China's real estate enterprises is gradually deepening.

3. The degree of financialization is not the most important factor affecting the profitability of real estate enterprises. The research results show that the growth ability of real estate enterprises and the turnover rate of total assets have a more significant positive correlation with corporate earnings, and the use of financial leverage will have a negative impact on corporate earnings. 
TABLE III. THE REGRESSION RESULTS OF FINANCIALIZATION OF REAL ESTATE ENTERPRISES

\begin{tabular}{|c|c|c|}
\hline & fe & fe_robust \\
\hline \multirow{2}{*}{ FIN } & $-0.186^{*}$ & $-0.186^{*}$ \\
\hline & $(-2.56)$ & $(-1.93)$ \\
\hline \multirow[b]{2}{*}{ LEV } & $-0.141 * * *$ & $-0.141 *$ \\
\hline & $(-3.87)$ & $(-1.81)$ \\
\hline \multirow{2}{*}{ GROWTH } & $0.0189 * * *$ & $0.0189 * * *$ \\
\hline & $(4.11)$ & $(2.77)$ \\
\hline \multirow{2}{*}{ TAT } & $0.140 * * *$ & $0.140 * *$ \\
\hline & $(4.71)$ & $(2.36)$ \\
\hline The year effect & control & control \\
\hline \multirow[b]{2}{*}{ _cons } & $0.112 * * *$ & $0.112 * *$ \\
\hline & $(4.21)$ & $(2.45)$ \\
\hline $\operatorname{Adj} \_R^{2}$ & 0.0296 & 0.127 \\
\hline $\mathbf{N}$ & 800 & 800 \\
\hline
\end{tabular}

\section{DISCUSSION}

The results show that there is a significant negative correlation between financialization of real estate enterprises and corporate profits, that is, the higher the proportion of financial assets held by enterprises, the closer the connection with financial institution, and the stronger the inhibiting effect on corporate profitability. This is mainly because financialization will change the asset allocation structure of real estate enterprises and deepen financial leverage to some extent while solving some problems of real estate enterprises. Financialization makes the asset allocation of enterprises deviate from the main business, and the economic resources of enterprises are scattered. The investment in the financial market squeezes the investment of operational business, restricts the development of main business, and gradually increases financial risks, which will eventually reduce the core competitiveness of enterprises and affect the overall profitability of enterprises.

As a capital-intensive industry, real estate enterprises have a high demand for capital, so they have a large proportion of cash assets. In order to maintain and increase the value of their capital, as well as to facilitate their expansion of financing channels and stable development of capital sources, they are becoming more and more enthusiastic about financial investment, so they are becoming more and more financialized.

\section{CONCLUSION}

This study mainly analyzes the financialization status of China's real estate industry from 2008 to 2017 and the relationship between financialization and corporate profitability. Through research and analysis, it clarifies the rising financialization trend of real estate enterprises and finds that financialization of real estate enterprises has a significant negative impact on corporate profitability, which gives the microeconomic effect of the financialization of real estate enterprises and reference significance to the financial supervision of the government.

\section{REFERENCES}

[1] Krippner, G. R . The financialization of the American economy[J]. Socio-Economic Review, 2005, 3(2):173-208.

[2] Lu Chunyi, Ding Xiaoqin. Political economy analysis of economic financialization- an evolutionary game framework [J]. Finance and economics research,2016,4207:52-62+74.

[3] Wang Renxiang, Guo Chunfeng. An empirical study on the impact of real estate price fluctuations on financial stability in China $[\mathrm{J}]$. Hainan finance, 2013,06:13-17.

[4] Sen S , Dasgupta Z . Financialization and Corporate Investments: The Indian Case[J]. Economics Working Paper Archive, 2015, 64(4):844853.

[5] CAI Mingrong, Ren Shichi. Financialization of enterprises: a review of research [J]. Science of finance and economics,2014,07:41-51.

[6] Smith C W, Stulz R M. The Determinants of Firms' Hedging Policies[J]. Journal of Financial \& Quantitative Analysis, 1985, 20(4):391-405.

[7] Hu Yiming, Wang Xueting, Zhang Jin. Motivation of financial asset allocation: "reservoir" or "replacement"? - Evidence from Chinese listed companies [J]. Economic research,2017,5201:181-194.

[8] Orhangazi Ö. Financialisation and capital accumulation in the nonfinancial corporate sector:A theoretical and empirical investigation on the US economy: 1973-2003[J]. Mpra Paper, 2008, 32(6):863-886.

[9] Duchin R, Gilbert T, Harford J, et al. Precautionary Savings with Risky Assets: When Cash Is Not Cash[J]. Journal of Finance, 2017, 72.

[10] Peng Yuchao, Han Xun, Li Jianjun. Economic policy uncertainty and financialization of enterprises $[\mathrm{J}]$. China industrial economy, 2008,01:137-155.

[11] Ortiz, J.P.D, Pablo, J..Financialization: The Aids of Economic System Ensayos de Economica, 2014, 23(44):429-445.

[12] Zhang Chengsi, Zhang Butan. The mystery of China's industrial investment rate decline: from the perspective of economic financialization $[\mathrm{J}]$. Economic research,2016,5112:32-46.

[13] Dai Ze, Peng Yuchao, Ma Sichao. Understanding the economic "disengagement from reality to emptiness" from a micro perspective -- a review of research on enterprise financialization $[\mathrm{J}]$. Foreign economics and management,2018,4011:31-43.

[14] Liu Duchi, He Yuping, Wang xi. Research on the impact of enterprise financialization on production efficiency of entity enterprises $[\mathrm{J}]$ Shanghai economic research,2016,08:74-83

[15] Wang Hongjian, Cao Yuqiang, Yang Qing, Yang Zheng. Does financialization of entity enterprises promote or inhibit enterprise innovation -- based on the experience of listed manufacturing companies in China [J]. Nankai management review,2017,2001:155-166. 